F. Reprod. Fert. (1970) 23, 257-261

\title{
ASYNCHRONY OF OVULATION AND MATING IN MICE TREATED WITH GONADOTROPHINS
}

\author{
S. STERN AND A. W. SGHUETZ \\ The Johns Hopkins University School of Hygiene and Public Health, \\ Department of Population Dynamics, 615 North Wolfe Street, Baltimore, \\ Maryland 21205, U.S.A.
}

(Received 7th November 1969, revised 22nd January 1970)

Summary. Adult mice, chosen without regard to the stage of the oestrous cycle, were injected with PMSG. This treatment resulted in ovulation in $77.9 \%$ of the animals, within $20 \mathrm{hr}$. The animals, however, did not mate in this time period. FSH or LH also induced ovulation in this time period.

These results are discussed in their relationship to normal ovulation and mating behaviour in the mouse.

\section{INTRODUGTION}

Ovulation in mammals is controlled by the action of gonadotrophic hormones on the ovary. Synchronization of ovulation and mating, and also of superovulation, can be initiated by the proper sequence of gonadotrophic hormone injections in adult mice (Fowler \& Edwards, 1957). Injection of pregnant mares serum gonadotrophin (PMSG), followed approximately $48 \mathrm{hr}$ later by human chorionic gonadotrophin (HCG), results in mating in a high proportion of animals and essentially $100 \%$ ovulation. Oocytes are usually found in the oviducts on the day following the HCG injection. Observations made by Fowler \& Edwards (1957), which we have confirmed, indicate that in a considerable number of animals so treated two types of oocytes are present in the oviducts.

The origin of these two types of oocytes is of interest. Either they are both ovulated at one time or more than one ovulation occurs in response to the gonadotrophin treatment. Previous investigations (Burdick, Watson, Ciampa \& Ciampa, 1943; Saunders, 1947) have demonstrated that, following a single injection of gonadotrophic hormone, ovulation can be induced in the postpuberal di-oestrous animals. In view of these facts, the effect of the PMSG on ovulation and mating in the post-puberal mouse during the immediate postPMSG-injection period has been investigated.

\section{MATERIALS AND METHODS}

Adult, random-bred, female Swiss mice (6 to 8 weeks of age) were obtained from a local breeder (Hazelton-Carbia, Burtonsville, Maryland). The animals were maintained in large cages (twenty-five per cage) on a light schedule of 
$14 \mathrm{hr}$ of light $/ 10 \mathrm{hr}$ of dark, for at least 1 week following arrival, before experimental use. The lights came on at 06.00 hours each day. In each experiment, the animals of a single shipment were randomized among experimental groups of equal size.

Animals were chosen without regard to the cycle, and injected intraperitoneally with gonadotrophic hormones or saline in a volume of $0.2 \mathrm{ml}$ or $0.9 \%$ saline between 13.00 and 14.30 hours. The dose of PMSG utilized in these studies ( 5 i.u.) was that routinely used in this laboratory for synchronization of ovulation and mating. Hormones injected were PMSG (Ayerst-Equinex) and pituitary preparations kindly supplied by the Endocrinology Study Section of NIH (NIH LH-S-13, ovine, NIH FSH-S-5, ovine). The mice were killed by cervical dislocation, approximately $20 \mathrm{hr}$ after the injections. Oviducts were removed and placed in drops of hyaluronidase $(300 \mathrm{U} / \mathrm{ml})$ in a petri dish. If the ampulla was swollen, the oviduct was cut with a 25-gauge needle and the oocytes released with gentle pressure. If the ampulla was not swollen, the oviduct was flushed with saline with the aid of a blunt 30-gauge needle. All oocytes released or flushed from the oviducts were counted. The presence of oocytes was taken as evidence of ovulation. The incidence of mating following hormonal treatment was also assessed. Following injection of gonadotrophic hormones or saline, all females were randomly placed with individual males at the same time on the same day. The presence of a vaginal plug the next morning was regarded as evidence of mating.

\section{RESULTS}

\section{Effect of PMSG on ovulation}

The injection of 5 i.u. of PMSG induced ovulation in $77.9 \%$ of the animals and these animals retained an average of 8.56 eggs in their oviducts. The incidence of spontaneous ovulation, as estimated in the controls injected with saline, was $5.5 \%$ with an average of 7.64 eggs in those animals which ovulated. The incidence of polar bodies was the same in the two groups, suggesting that the oocytes in the PMSG group had undergone maturation. These data are presented in Table 1.

\section{Induction of mating}

The incidence of mating following PMSG injection was determined on the morning following the injection. The results are presented in Table 2. The incidence of mating was markedly increased in those animals injected with both PMSG and HCG as compared to the controls treated with saline. Mating behaviour in PMSG-injected animals was not different from the controls treated with saline.

\section{Effect of FSH and LH}

Since PMSG contains both FSH and LH activity, it is not clear which of the factors was the stimulator of ovulation. In order to assess which activity was important for the induction of ovulation, animals were injected with either purified mammalian pituitary FSH or LH. The results presented in Table 3 clearly indi- 
TABLE 1

OVULATION IN RESPONSE TO PMSG INJEGTION IN MIGE

\begin{tabular}{|c|c|c|c|c|c|c|}
\hline \multirow[b]{2}{*}{ Exp. } & \multicolumn{3}{|c|}{ Saline } & \multicolumn{3}{|c|}{$P M S G$} \\
\hline & $\begin{array}{l}\text { No. ovulating/ } \\
\text { animals injected }\end{array}$ & $\begin{array}{l}\text { Total } \\
\text { eggs }\end{array}$ & $\begin{array}{l}\text { Average no. } \\
\text { eggs/animal } \\
\text { ovulating }\end{array}$ & $\begin{array}{l}\text { No. ovulating/ } \\
\text { animals injected }\end{array}$ & $\begin{array}{l}\text { Total } \\
\text { eggs }\end{array}$ & $\begin{array}{l}\text { Average no. } \\
\text { eggs/animal } \\
\text { ovulating }\end{array}$ \\
\hline $\begin{array}{l}1 \\
2 \\
3 \\
4 \\
5 \\
6 \\
7 \\
8 \\
9\end{array}$ & $\begin{array}{l}1 / 10 \\
1 / 10 \\
1 / 10 \\
0 / 10 \\
3 / 15 \\
2 / 20 \\
0 / 25 \\
0 / 25 \\
0 / 20\end{array}$ & $\begin{array}{r}11 \\
6 \\
15 \\
0 \\
18 \\
11 \\
0 \\
0 \\
0\end{array}$ & $\begin{array}{r}11 \cdot 00 \\
6.00 \\
15.00 \\
0.00 \\
6.00 \\
5.50 \\
0.00 \\
0.00 \\
0.00\end{array}$ & $\begin{array}{r}7 / 10 \\
7 / 10 \\
10 / 10 \\
7 / 10 \\
11 / 15 \\
16 / 20 \\
19 / 25 \\
21 / 25 \\
15 / 20\end{array}$ & $\begin{array}{r}56 \\
64 \\
67 \\
73 \\
93 \\
151 \\
132 \\
202 \\
128\end{array}$ & $\begin{array}{l}8 \cdot 00 \\
9 \cdot 14 \\
6 \cdot 70 \\
7 \cdot 30 \\
8 \cdot 45 \\
9 \cdot 44 \\
6 \cdot 95 \\
9 \cdot 62 \\
8 \cdot 53\end{array}$ \\
\hline & $8 / 145$ & 61 & $7 \cdot 64$ & $113 / 145$ & 966 & 8.56 \\
\hline
\end{tabular}

TABLE 2

INDUCTION OF MATING AFTER GONADOTROPHIC HORMONE INJECTION IN MICE

\begin{tabular}{l|c|c}
\hline \multicolumn{1}{c|}{ Treatment } & No. of animals & No. mating \\
\hline Saline* & 65 & 2 \\
PMSG* & 65 & 5 \\
PMSG and HCG* & 50 & 30 \\
\hline
\end{tabular}

* All animals were placed with males at the same time. The HCG was administered at the same time as the PMSG and saline of the other groups, $48 \mathrm{hr}$ after the initial PMSO injection.

TABLE 3

PRECOGIOUS OVULATION RESPONSE TO FSH AND LH IN MICE

\begin{tabular}{l|c|c|c}
\hline & $\begin{array}{c}\text { Animals ovulating } \\
\text { no. injected }\end{array}$ & $\begin{array}{c}\text { Total eggs } \\
\text { recovered }\end{array}$ & $\begin{array}{c}\text { Eggs/animal } \\
\text { ovulating }\end{array}$ \\
\hline $\begin{array}{c}\text { FSH }(\mu \mathrm{g}) \\
1\end{array}$ & $6 / 40$ & 37 & $6 \cdot 17$ \\
10 & $19 / 38$ & 114 & $6 \cdot 00$ \\
100 & $25 / 40$ & 147 & $5 \cdot 88$ \\
\hline LH $(\mu \mathrm{g})$ & $9 / 40$ & 67 & $7 \cdot 44$ \\
10 & $17 / 40$ & 97 & $5 \cdot 71$ \\
100 & $23 / 40$ & 110 & $4 \cdot 78$ \\
\hline PMSG & $31 / 40$ & 279 & $9 \cdot 00$ \\
Saline & $2 / 40$ & 11 & $5 \cdot 50$ \\
\hline
\end{tabular}

Summary of two experiments. The saline and PMSG controls are also listed in Table 1 as Exps 6 and 9. 
cate that either hormone was effective in inducing ovulation. The administration of combinations of FSH and LH also resulted in ovulation within $20 \mathrm{hr}$, with little evidence of any synergistic activity between these two hormones.

\section{DISCUSSION}

The data presented here show that ovulation is induced in the post-puberal mouse within $20 \mathrm{hr}$ of gonadotrophic hormone injection (PMSG, FSH, LH). Thus, the regimen of gonadotrophin injections (PMSG-HGG) utilized to synchronize ovulation and mating in the post-puberal female mouse (Fowler \& Edwards, 1957) is in all probability inducing the ovulation of at least two different sets of oocytes: an initial set ovulated within $20 \mathrm{hr}$ of the PMSG injection, and a second set ovulated in response to the HCG administered $48 \mathrm{hr}$ after the PMSG injection. However, stimulation of mating behaviour is not induced concurrently with the initial induction of ovulation.

The initial oocytes ovulated as a result of the PMSG would never be fertilized since they are released during a period in which the animals do not mate. At present, it is not clear what the physiological action of the administered hormone is nor what the fate of the released oocytes would have been in the absence of exogenous hormone. There may be a relationship between these oocytes and those studied by Donahue (1968), who showed that there is present in the ovary of the post-puberal mice a population of oocytes, which, when mechanically released from follicles, will undergo an apparently normal meiotic maturation in vitro.

Several recent studies (Peters, 1969; Pedersen, 1969) have indicated that a variety of follicle types, containing oocytes at different stages of development and atresia, exists in the ovary of mature mice at any given time. Peters (1969) suggests that oocytes undergoing atresia can be released from follicles through the ovarian epithelium, so it is possible that some of the oocytes recovered in the present study would normally have undergone atresia.

The present experiments confirm the previous results (Burdick et al., 1943; Saunders, 1947) even though the animals were chosen without regard to the cycle. We have also shown that mating is not a consequence of the PMSGinduced ovulation.

Attempts are being made to test the capacity of oocytes to undergo fertilization and subsequent development.

\section{AGKNOWLEDGMENTS}

This work was supported in part by grants from the Population Council and the National Institutes of Health (NIH 1 R0I HD03797 and NICHHD 5 T01 HD 00109 ).

\section{REFERENCES}

Burdick, H. O., Watson, H., Ciampa, V. \& Ciampa, T. (1943) A rapid test for pregnancy gonadotropins on the basis of induced ovulation in mice. Endocrinology, 33, 1.

Donahue, R. P. (1968) Maturation of the mouse oocyte in vitro. I. Sequence and timing of nucle a progression. J.exp. Zool. 169, 237. 
FowLER, R. E. \& EDWARDs, R. G. (1957) Induction of superovulation and pregnancy in mature mice by gonadotrophins. J. Endocr. 15, 374.

Pedersen, T. (1969) Follicle growth in the immature mouse ovary. Acta endocr., Copenh. 62, 117.

Perres, H. (1969) The development of the mouse ovary from birth to maturity. Acta endocr., Copenh. 62, 98.

SAUNDRRs, J. (1947) Induction of ovulation in the di-oestrous mouse by gonadotropins. Endocrinology, 40, 1 . 